\title{
Affinity Chromatography of Neutral Proteinase from Streptomyces naraensis on a Column of $N$-Carbobenzoxy-L-phenylalanyl- aminohexyl-Sepharose $^{\dagger}$
}

\author{
Akira HiRAmatsu \\ Department of Agricultural Chemistry, Faculty of Agriculture, \\ Ibaraki University, Ami, Ibaraki 300-03, Japan
}

Received April 23, 1981

\begin{abstract}
$\mathrm{N}$-Carbobenzoxy-L-phenylalanyl-aminohexyl-Sepharose (Z-Phe-AH-Sepharose) was found to be an effective affinity adsorbent for neutral proteinase from Streptomyces naraensis. This enzyme was adsorbed on this affinity column at $\mathrm{pH} 7.0$ or higher, and eluted with $0.3 \mathrm{M} \mathrm{NaCl}$ in starting buffer. The resulting enzyme appeared homogeneous on disc electrophoresis and showed considerably higher specific activity and recovery than by previous method.
\end{abstract}

In the previous studies of this series, ${ }^{1 \sim 4)}$ a neutral proteinase [EC 3.4.24 group] was purified from the culture media of Streptomyces naraensis to an electrophoretically homogeneous state by fractionation with acetone, gel filtration on Sephadex G-100 and column chromatography on DEAE-cellulose. The enzymatic $^{1)}$ and protein chemical properties ${ }^{3)}$ of this enzyme, containing $1 \mathrm{~g}$-atom of zinc per mol of enzyme protein ${ }^{4}$ (based on a molecular weight of 37,000), were reported by the author and Ouchi.

Affinity chromatography of metalloenzymes, which are common among neutral proteolytic enzymes (endopeptidases) from microorganisms, has been reported by some investigators: neutral proteinase from Clostridium histolyticum by Sparrow and McQuade, ${ }^{5)}$ neutral subtilopeptidase amylosacchariticus and thermolysin from Bacillus species by Fujiwara et al., ${ }^{6)}$ and Komiyama et $a .^{7)}$

$N$-Carbobenzoxy-L-phenylalanyl-aminohexyl-Sepharose was found to be an effective affinity adsorbent for purifying neutral proteinase from Streptomyces naraensis by

$\dagger$ Neutral Proteinase from Streptomyces naraensis. Part V. For Parts I IV, see ref. 1 4.

This work was presented at the Annual Meeting of the Agricultural Chemical Society of Japan, Yokohama, 1977. affinity chromatography.

On the other hand, inhibition by carbobenzoxy-amino acid and peptides on the activity of neutral subtilopeptidase was reported by Morihara et al. ${ }^{8)}$

The activity of neutral proteinase from Streptomyces naraensis was inhibited by carbobenzoxy amino acids (Z-Phe-OH, and ZLeu-OH*1), which were found to be competitive inhibitors. The inhibition by carbobenzoxy amino acids of the enzyme will be reported in the subsequent paper.*2

The present paper reported that the neutral proteinase from Streptomyces naraensis can be purified by affinity chromatography, using a column of $N$-carbobenzoxy-L-phenylalanyl-aminohexyl-Sepharose (Z-Phe-AHSepharose).

\section{MATERIALS AND METHODS}

Chemicals. 1-Cyclohexyl-3-(2-morpholinoethyl)carbodiimide metho-p-toluene sulfonate (CMC) was purchased from Nakarai Chemical Co., carbobenzoxy amino acids such as Z-Phe-OH and Z-Leu-OH were obtained from the Peptide Institute, Protein Research Foun-

*1 Abbreviations: Z-Phe-OH, carbobenzoxy-L-phenylalanine, Z-Leu-OH, carbobenzoxy-L-leucine.

*2 Neutral Proteinase from Streptomyces naraensis. Part VII. 
dation, and $N$-aminohexylamino-Sepharose 4B (AHSepharose) was a product of Pharmacia Fine Chemicals Co.

Enzyme preparation. The neutral proteinase from Streptomyces naraensis chromatographed on a column of Sephadex G-100 was prepared by the method described previously. ${ }^{3)}$ The specific activity of the gel filtrated enzyme was 1271 mkat per $\mathrm{kg}$ of protein.

Assay for proteinase activity. Proteinase activity was measured by the casein-275 $\mathrm{nm}$ method of Hagiwara et $a l .{ }^{9)}$ as described previously. ${ }^{1)}$

Assay for protein concentration. The protein concentration of each fraction was measured at $280 \mathrm{~nm}$ using $E_{1 \mathrm{~cm}}^{1 \%}=11.22$ or by Lowry et al. 's ${ }^{10)}$ method as described previously. ${ }^{1)}$

Zinc analysis. Zinc was determined by atomic absorption spectrophotometry as described previously. ${ }^{4)}$

Disc electrophoresis. Disc electrophoresis of the enzyme was performed by the method of Ornstein ${ }^{11)}$ and Davis ${ }^{12}$ ) as described previously. ${ }^{3)}$

Preparation of $N$-carbobenzoxy-L-phenylalanyl- (Z-PheAH-Sepahrose) and $N$-carbobenzoxy-L-leucyl-aminohexylSepharose (Z-Leu-AH-Sepharose). Five g of $\mathrm{N}$-aminohexylamino-Sepharose 4B (AH-Sepharose) washed with $0.5 \mathrm{M} \mathrm{NaCl}$ and deionized water was mixed with $24 \mathrm{mg}$ of CMC and $150 \mathrm{mg}$ of Z-Phe-OH or Z-Leu-OH in $20 \mathrm{ml}$ of $40 \% \mathrm{~N}, \mathrm{~N}$-dimethylformamide solution at $\mathrm{pH} 5.0$, and then left at room temperature with gentle shaking for one day. After the reaction, the gels were washed successively with $1 \mathrm{M} \mathrm{NaCl}$ containing $40 \% \mathrm{~N}, \mathrm{~N}$-dimethylformamide, $1 \mathrm{M} \mathrm{NaHCO}$, deionized water, $1 \mathrm{M}$ acetic acid and finally with deionized water, and were then stored in the cold until use. These Z-Phe-AH- and Z-Leu-AHSepharoses were found to contain $6 \mu \mathrm{mol}$ of phenylalanine and $10 \mu \mathrm{mol}$ of leucine per $\mathrm{g}$ of dried gel, respectively.

Affinity chromatography. The gel filtrated enzyme solution was chromatographed on columns $(0.5 \times 1.5 \mathrm{~cm})$ of Z-Phe-AH-, Z-Leu-AH-, or AH-Sepharose, which had been equilibrated with $0.033 \mathrm{M}^{* 3}$ veronal-sodium acetate$\mathrm{HCl}$ buffer (Michaelis) at various $\mathrm{pHs}$ containing $0.01 \mathrm{M}$ calcium acetate (ionic strength, $\mu=0.05$ ). The enzyme was eluted with linearly increasing concentrations of $\mathrm{NaCl}$ in starting buffer, at a flow rate of $19.5 \mathrm{ml}$ per $\mathrm{hr}$, and fractions of $1.7 \mathrm{ml}$ were collected. The liquid from each tube was subjected to measurement for enzymatic activity and protein concentration.

*3 The concentration of buffer solution is expressed in mol of veronal.

\section{RESULTS}

Effect of $p H$ on adsorption of the neutral proteinase on the affinity chromatography

The effect of $\mathrm{pH}$ on adsorption of the enzyme on the affinity chromatography using columns of Z-Phe-AH-, Z-Leu-AH-, or AHSepharose, which had been equilibrated with $0.033 \mathrm{M}$ veronal-sodium acetate- $\mathrm{HCl}$ buffer at various $\mathrm{pHs}$ containing $0.01 \mathrm{M}$ calcium acetate was studied.

The enzyme was adsorbed on columns of ZPhe-AH- or Z-Leu-AH- Sepharose at pH 7.0 or higher. But this enzyme was not adsorbed on columns of AH-Sepharose at $\mathrm{pH} 7.2$ or lower, or of Z-Phe-AH- or Z-Leu-AH-Sepharose at $\mathrm{pH} 6.5$, respectively. Elution profiles of the neutral proteinase on columns of Z-Phe-AH-, Z-Leu-AH-, or AH-Sepharose are shown in Fig. 1. The enzyme adsorbed on columns of Z-Phe-AH- or Z-Leu-AHSepharose was eluted with $0.3 \mathrm{M} \mathrm{NaCl}$ in the

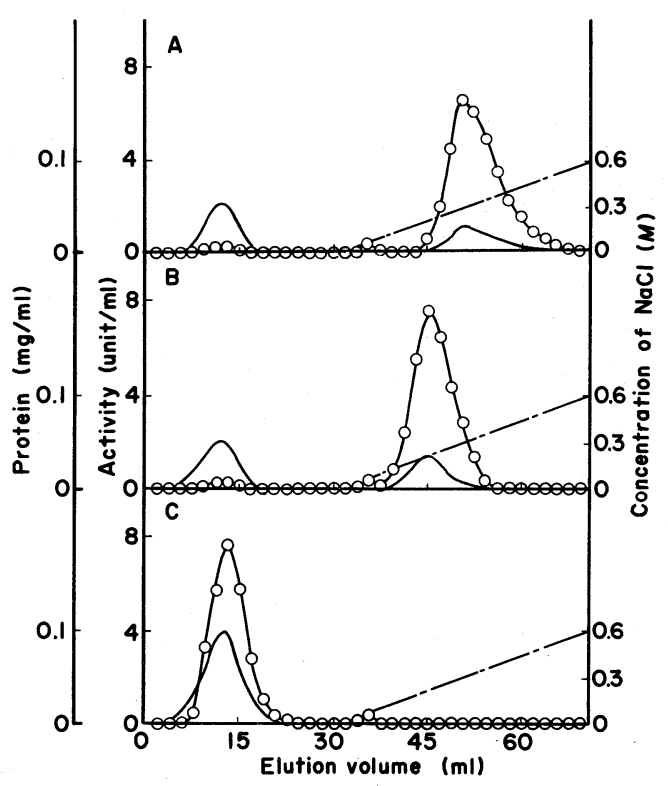

FIG. 1. Elution Profiles of Neutral Proteinase.

The procedure was given in Materials and Methods except that $0.033 \mathrm{M}$ veronal-sodium acetate- $\mathrm{HCl}$ buffer, $\mathrm{pH} 7.0$, containing $0.01 \mathrm{M}$ calcium acetate was used. The columns used were Z-Phe-AH- (A), Z-Leu-AH- (B), and AH-Sepharose (C), respectively, _ , ultraviolet absorption at $280 \mathrm{~nm}$; $-\mathrm{O}-$, proteolytic activity: -.concentration of $\mathrm{NaCl}$. 
starting buffer at $\mathrm{pH} 7.0$ for Z-Phe-AH-Sepharose and with $0.2 \mathrm{M} \mathrm{NaCl}$ in the same buffer for Z-Leu-AH-Sepharose, respectively.

Improved purification using affinity chromatography

A neutral proteinase was purified by an improved method using gel filtration on Sephadex G-100 and column chromatography on Z-Phe-AH-Sepharose.

The neutral proteinase purified on the col-

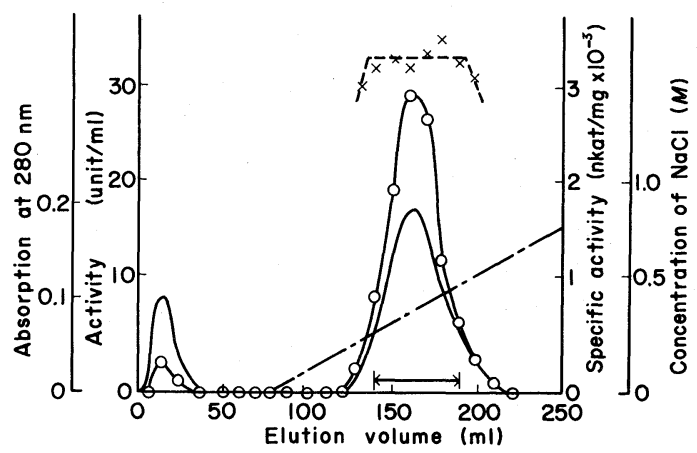

FIG. 2. Affinity Chromatography of Neutral Proteinase. Enzyme solution $(16 \mathrm{ml})$ fractionated by chromatography on Sephadex G-100 was placed on the top of a column $(1.0 \times 6.2 \mathrm{~cm})$ of Z-Phe-AH-Sepharose which had been equilibrated with $0.025 \mathrm{M}$ Tris- $\mathrm{HCl}$ buffer, $\mathrm{pH} 7: 2$, containing $0.01 \mathrm{M}$ calcium acetate. The enzyme was eluted with linearly increasing concentrations of $\mathrm{NaCl}$ from 0 to $0.7 \mathrm{M}$ in the starting buffer. The flow rate was $26.6 \mathrm{ml}$ per $\mathrm{hr}$ and fractions of $5 \mathrm{ml}$ were collected. The horizontal arrow indicates fractions pooled. - ultraviolet absorption at $280 \mathrm{~nm}$; - $\mathrm{O}-$, proteolytic activity; --- $\times---$, specific activity; - - - concentration of $\mathrm{NaCl}$. umn of Sephadex G-100 was applied on a column $(1.0 \times 6.2 \mathrm{~cm})$ of Z-Phe-AH-Sepharose which had been equilibrated with $0.025 \mathrm{M}$ Tris$\mathrm{HCl}$ buffer at $\mathrm{pH} 7.2$ containing $0.01 \mathrm{M}$ calcium acetate. After the column was washed with the starting buffer, the enzyme was eluted with linearly increasing concentrations of $\mathrm{NaCl}$ in the starting buffer, at a flow rate of $26.6 \mathrm{ml}$ of per hr, and fractions of $5 \mathrm{ml}$ were collected. As shown in Fig. 2, after elution with $150 \mathrm{ml}$ of the starting buffer, a reservoir containing the second buffer $(0.025 \mathrm{M}$ Tris- $\mathrm{HCl}$ buffer at $\mathrm{pH}$ 7.2 containing $0.01 \mathrm{M}$ calcium acetate and $0.7 \mathrm{M}$ sodium chloride, $150 \mathrm{ml}$ ) was connected to the mixing chamber filled with $150 \mathrm{ml}$ of the starting buffer.

For further purification, the fractions indicated by the horizontal arrow in Fig. 2 containing enzyme were combined and dialyzed against $0.005 \mathrm{~m}$ calcium acetate at $\mathrm{pH}$ 7.5.

The results of the purification procedures are summarized in Table I. The specific activity of this highly purified neutral proteinase was 3212 mkat per $\mathrm{kg}$ of protein, and $12 \mathrm{mg}$ of enzyme protein was obtained from $330 \mathrm{ml}$ of culture media with a yield of 63 per cent.

On acrylamide gel electrophoresis, the purified enzyme migrated to the anode as a single band.

This purified enzyme was confirmed to contain $1.0 \mathrm{~g}$-atom of zinc per mol of enzyme $\left(2.75 \times 10^{-8} \mathrm{~mol}\right.$ of zinc per $\mathrm{mg}$ of protein),

Table I. Purification of Neutral Proteinase from Streptomyces naraensis

One unit of the proteolytic activity was defined as the amount of enzyme that liberated trichloroacetic acid soluble hydrolysate from casein corresponding to one $\mu \mathrm{mol}$ of L-tyrosine per min per ml of enzyme solution at $40^{\circ} \mathrm{C}$.

\begin{tabular}{lcccc}
\hline \multicolumn{1}{c}{ Fraction } & $\begin{array}{c}\text { Total } \\
\text { protein } \\
(\mathrm{mg})\end{array}$ & $\begin{array}{c}\text { Total } \\
\text { activity } \\
\text { (units) }\end{array}$ & $\begin{array}{c}\text { Specific } \\
\text { activity } \\
(\mathrm{mkat} / \mathrm{kg})\end{array}$ & $\begin{array}{c}\text { Recovery } \\
(\%)\end{array}$ \\
\hline $\begin{array}{l}\text { Crude enzyme solution } \\
\text { Acetone precipitation }\end{array}$ & 3,044 & 3,653 & 20 & 100 \\
$\begin{array}{l}\text { Sepahdex G-100 } \\
\text { chromatography }\end{array}$ & 213 & 3,288 & 258 & 90 \\
$\begin{array}{l}\text { Z-Phe-AH-Sepharose } \\
\text { affinity chromatography }\end{array}$ & 37 & 2,815 & 1,271 & 77 \\
\hline
\end{tabular}


based on a molecular weight of 37,000 and from the zinc content determined by the atomic absorption spectrophotometric method.

\section{DISCUSSION}

Sparrow and McQuade ${ }^{5)}$ reported that the neutral proteinase from Clostridium histolyticum was adsorbed on a column of Sepharoylcaproyl-glycyl-L-leucine (Sepharoyl-Cap-GlyLeu-OH), equilibrated with the starting buffer at $\mathrm{pH} 7.2$, and eluted with $0.05 \mathrm{M}$ Tris at $\mathrm{pH} 10$.

Fujiwara et $a l .{ }^{6)}$ reported that neutral subtilopeptidase and thermolysin were adsorbed on a column of carbobenzoxy- L-phenylalanyltriethylenetetraaminyl-Sepharose (Z-Phe-TSepharose), equilibrated with the starting buffer at $\mathrm{pH} 7.2$, and eluted with $0.05 \mathrm{M}$ borate buffer containing $0.5 \mathrm{M} \mathrm{NaCl}$ at $\mathrm{pH} 9.0$ for neutral subtilopeptidase and $1.5 \mathrm{M}$ guanidine in the starting buffer at $\mathrm{pH} 7.2$ for thermolysin, respectively.

Komiyama et $a l .{ }^{7)}$ reported that neutral subtilopeptidase and thermolysin were adsorbed on a column of phosphoramidonSepharose, equilibrated with the starting buffer at $\mathrm{pH} 7.0$, and eluted with $1.0 \mathrm{M} \mathrm{NaCl}$ in $0.1 \mathrm{M}$ Tris- $\mathrm{HCl}$ buffer at $\mathrm{pH} 9.0$ for neutral subtilopeptidase, and $1.0 \mathrm{M}$ guanidine- $\mathrm{HCl}$ in $0.1 \mathrm{M}$ Tris- $\mathrm{HCl}$ buffer at $\mathrm{pH} 9.0$ for thermolysin, respectively.

The author confirmed that the neutral proteinase from Streptomyces naraensis was not adsorbed on a column of Sepharoyl-Cap-GlyLeu-OH when adjusted at $\mathrm{pH}$ 7.2. The neutral proteinase is highly purified by affinity chro- matography, when adsorbed on a column of Z-Phe-AH-Sepharose at neutral $\mathrm{pH}$ and eluted successfully with $0.3 \mathrm{M} \mathrm{NaCl}$ in the starting buffer (Fig. 3). The enzyme was isolated by the improved purification method with a yield of about 63 per cent, considerably higher than by previous method. ${ }^{3)}$ This purified enzyme is homogeneous on disc electrophoresis and contains $1 \mathrm{~g}$-atom of zinc per mol of enzyme protein.

Acknowledgments. The author is indebted to Mr. S. Kasahara and Mr. K. Oyamada of Nikken Kagaku Co. for supplying the culture media of Streptomyces naraensis, and to Mr. M. Yoshida for his technical cooperation.

\section{REFERENCES}

1) A. Hiramatsu, J. Biochem., 62, 353 (1967).

2) A. Hiramatsu, J. Biochem., 62, 364 (1967).

3) A. Hiramatsu and T. Ouchi, J. Biochem., 71, 767 (1972).

4) A. Hiramatsu and T. Ouchi, Agric. Biol. Chem., 42, 1309 (1978).

5) L. G. Sparrow and A. B. McQuade, Biochim. Biophys. Acta, 302, 90 (1973).

6) K. Fujiwara, K. Osue and D. Tsuru, J. Biochem., 77, 739 (1975).

7) T. Komiyama, T. Aoyama, T. Takeuchi and H. Umezawa, Biochem. Biophys. Res. Commun., 65, 352 (1975).

8) K. Morihara, T. Oka and H. Tsuzuki, Arch. Biochem. Biophys., 132, 480 (1968).

9) B. Hagiwara, N. Matsubara, J. Nakai and K. Okunuki, J. Biochem., 45, 185 (1957).

10) O. H. Lowry, N. J. Rosebrough, A. L. Farr and R. J. Randall, J. Biol. Chem., 193, 265 (1951).

11) L. Ornstein, Ann. New York Acad. Sci., 121, 321 (1964).

12) B. J. Davis, Ann. New York Acad. Sci., 121, 406 (1964). 